\title{
UAB „TEIDA“ PREKĖS ŽENKLO VERTYBINIŲ ASOCIACIJŲ VERTINIMAS
}

\author{
Jüratè Leonavičienè, \\ Klaipédos valstybine kolegija \\ Jolanta Kreišmoniene \\ Klaipédos valstybine kolegija \\ DOI: https://doi.org/10.52320/svv.v0iVI.196
}

\begin{abstract}
Anotacija
Straipsnyje pateikiamas UAB „Teida“ prekès ženklo vertybinès asociacijos vartotojų požiūriu. Prekès ženklo asociacijų palankumas, unikalumas bei stiprumas nulemia vartotojų gebejjimą išskirti prekès ženklą iš kitų, padeda vartotojui apdoroti informaciją, suformuoja teigiamą požiūrị ne tik i pati ženklą, bet ir i prekę, ir padeda apsispręsti dėl pirkimo. Prekès ženklo kūrimo tikslas yra parengti turiningą prekès ženklo įvaizdžių ir asociacijų sistemą, o tiesiausias kelias sustiprinti vartotojų lojalumą prekès ženklui - didinti vartotojų emocini prisirišimą. Apibendrinti apklausos rezultatai parodė, kad prekès ženklas „Teida“ asocijuojasi su įmonės deklaruojamomis vertybėmis - sveikata ir profesionalumu, respondentams, pagalvojus apie "Teida” prekès ženklą, jų pasąmonèje kyla teigiamos, teisingai atpažintos asociacijos.
\end{abstract}

Pagrindiniai žodžiai: prekès ženklas, vertybinès asociacijos, vartotojų lojalumas.

\section{Ivadas}

Temos aktualumas. Prekès ženklas įtakoja vartotojų elgseną ir sprendimus, pasirenkant tam tikrą produktą, tačiau neapsiriboja vien tik pardavimo atpažinimu. Nepaprastai svarbu, kokias asociacijas ir mintis sukelia prekès ženklas, kada pirkèjas bando jị suvokti. Prekių ženklų logotipai ir spalvos simbolizuoja įmonių pažadą rinkai, kad vartotojų lūkesčiai bus patenkinti, nepaisant to, kokie įmantrūs jie būtų. Siejant prekès ženklą su įmone, jis turi asocijuotis su įmonès kultūra, vertybèmis, pirmenybę skiriant inovacijoms, kokybei, kartu orientuojantis į vartotoją, jo pomėgius bei lūkesčius. Toks prekès ženklas labiau vertinamas rinkoje, be to ji sunkiau nukopijuoti konkurentams, jis tampa imonès konkurencinio pranašumo šaltiniu bei kuriančiu vertę vartotojams (Vainauskienè ir Vaitkienė, 2016). Prekès ženklas kuriamas remiantis prekès unikalumu ir išskirtinėmis savybėmis, vertingomis vartotojui. Jei prekès ženklas rinkoje vertinamas gerai, įmonè prekes su šiuo ženklu gali parduoti brangiau nei panašias prekes gali parduoti konkurentai, o palankūs įmonès įvaizdžio vertinimai leidžia efektyviau igyvendinti ịmonès rinkodaros strategiją ir užimti stiprias pozicijas rinkoje (Jobber, 2010).

Šiuo metu Lietuvos rinkoje yra nemažai specializuotas sveikatos priemones teikiančiu įmonių. UAB „Teida“ - tai įmonè daugiau nei 25 metus sèkmingai veikianti rinkoje. UAB „Teida“ aprūpina didžiausias Lietuvos reabilitacijos ir sporto, slaugos ir kitas ịstaigas reabilitacine bei ortopedine technika bei sporto medicinos įranga, tiekia neigaliųų techniką, siūlo medicinos ịrangos, neigaliuju technikos, deguonies aparatų nuomos ir techninio aptarnavimo paslaugas bei vykdo mokymus reabilitacijos specialistams. Imonès prekinio ženklo „Sveikatos reikmenų“ parduotuvèse visoje Lietuvoje klientai gauna kineziterapeuto ar ergoterapeuto konsultacijas, įsigydami kineziterapinę ar ortopedinę priemonę, gali pasidaryti skaitmeninį pėdų tyrimą. Šiuo metu Lietuvoje atidarytos 6 įmonès parduotuvès.

Tyrimo problema. UAB „Teida“ prekès ženklo asociacijos vartotojų požiūriu nèra tirtos. Norint išlaikyti lyderystę ir stiprias pozicijas rinkoje, būtina nuolat ieškoti naujovių, sekti vartotojų nuotaikas, pažinti jų pasąmonèje suformuotą prekès ženklo vaizdą, todèl atliktas tyrimas leis nustatyti UAB „Teida“ prekès ženklo vertybines asociacijas, bei ịvertinti jų atitikimą įmonès siekiams.

Tyrimo objektas - UAB ,Teida“ prekès ženklo vertybinès asociacijos.

Tyrimo tikslas - įvertinti UAB „Teida“ prekès ženklo vertybines asociacijas.

Tyrimo uždaviniai:

1. Išnagrinèti prekès ženklo vertybines asociacijas teoriniu aspektu.

2. Nustatyti pagrindines prekès ženklo savybes ir vertybines asociacijas, kurias kelia prekès ženklas UAB ,Teida“ vartotojams.

Tyrimo metodika. Siekiant ịvertinti UAB „Teida“ prekès ženklo vertybines asociacijas, 2020 m. balandžio - rugpjūčio mèn. buvo atliktas kokybinis ir kiekybinis tyrimai. Su įmonès „Teida“ 
vadove buvo atliktas nestruktūruotas interviu, siekiant nustatyti, su kokiomis vertybinėmis asociacijomis ji sieja prekès ženklą „Teida“ ir kokio atpažinimo ji tikisi iš savo klientų. Kiekybinis tyrimas vykdytas pasitelkiant duomenų rinkimo būdą - anketavimą elektroniniu būdu. Parengta anketa buvo patalpinta internetiniame puslapyje www.manoapklausa.lt. Kvietimas dalyvauti tyrime, pateikiant nuorodą $\mathfrak{i}$ internete patalpintą anketą, taip pat buvo siunčiamas elektroniniu paštu įmonei „Teida“, kuri ją persiuntė savo nuolatiniams klientams. Anketoje buvo pateikti uždari klausimai, su nurodytais atsakymų variantais, ir pusiau uždari klausimai, ị kuriuos respondentas atsakymą galejjo pateikti pats. Respondentams atrinkti buvo naudojama atsitiktiné tikimybiné atranka. Tyrime dalyvavo 344 asmenys. Duomenų analizė atlikta, taikant socialiniams tyrimams skirtą SPSS programą, apibendrinti duomenys pateikiami diagramose, formuluojamos išvados.

\section{Prekès ženklo vertybinių asociacijų teorinė analizė}

Mokslinėje literatūroje nurodoma, kad prekès ženklas yra suteikiamas prekėms, kurias norima išskirti. Populiarūs, atpažįstami prekių ženklai suteikia vartotojams pasitikèjimo perkant, padeda renkantis iš gausybès pasiūlymų, ir, tokiu būdu, skatina vartotojus priimti ịmonei palankų sprendimą. Kaip nurodo Blackett ir kt. (2011), prekès pasirinkimą iš gausybės rinkoje esančių pasiūlymų, galiausiai nulemia prekès ženklas ir jo poveikis vartotojų pasąmonei. Prekès ženklo pozicija rinkoje gali kisti priklausomai nuo to, kaip įmonè sugebès tinkamai pateikti vartotojui prekès ženklą, t.y. nuo identiteto, ir nuo to, kaip vartotojas supras jam siunčiamą žinutę, t.y. nuo įvaizdžio. Taigi, prekès ženklo identitetą kuria ịmonè, o ịvaizdis susiformuoja vartotojo sąmonëje. Prekès ženklo identiteto koncepciją apima tai, kas suteikia prekès ženklui unikalumą, reikšmingumą ir išskirtinumą (Aaker ir Joachimsthaler, 2003). Identitetas, kaip asociacijų rinkinys, turi padèti sukurti ryši tarp prekès ženklo ir vartotojo, perteikdamas jam tam tikrą naudą. Asociacijos priklauso nuo to, kaip vartotojų pasąmonèje formuojamas prekès ženklo vaizdas. Navicko ir Malakauskaitès (2007) nuomone, identitetas - tai vertybių, požiūrių ir idejjų visuma, kuria įmonè siekia save pristatyti, o ịvaizdis išreiškia vartotojų suvokimą apie produktą ar prekès ženklą. Identitetas gali būti ịvardijamas kaip būdas, kuriuo įmonė siekia pristatyti save rinkai, o įvaizdis - įmonès ir jos produktų suvokimas vartotojo akimis.

Asociacijos yra svarbiausias veiksnys skatinantis pirkejjų apsisprendimą pirkti. Vartotojui pažįstant prekès ženklą, jo sąmonèje ịsitvirtina savybių ir naudos asociacijos bei teigiamos arba neigiamos nuostatos apie prekès ženklą (Belén del Río, Vázquez and Iglesias, 2001). Asociacijos priklauso nuo to, kaip vartotojų pasąmonèje formuojamas prekès ženklo vaizdas. Prekès ženklo asociacijų palankumas, unikalumas bei stiprumas nulemia vartotojų gebėjimą išskirti prekès ženklą tarp konkuruojančių ženklų (Keller, 2008). Taip pat prekès ženklo asociacijos padeda vartotojui apdoroti informaciją, suformuoja teigiamą požiūrị ne tik ị pati ženklą, bet ir ị prekę, ir padeda apsispręsti dèl pirkimo. Vainauskienė ir Vitkiené (2016) pažymi, jog vartotojų lojalumas prekès ženklui būtent ir formuojasi teigiamų prekès ženklo asociacijų pagrindu. Prekès ženklo kūrimo tikslas yra parengti turiningą prekès ženklo įvaizdžių ir asociacijų sistemą, o tiesiausias kelias sustiprinti vartotojų lojalumą prekès ženklui - didinti vartotojų emocinį prisirišimą.

Mokslinèje literatūroje asociacijų vaidmuo bei grupavimas aptariamas gana skirtingai. Keller (2008) išskiria tris prekès ženklo asociacijų kategorijas: funkcinès asociacijos, emocinès arba simbolinès asociacijos ir patyrimas. Funkcinės asociacijos apima apčiuopiamus prekių ar paslaugu požymius, emocinès - neapčiuopiamus požymius, atspindinčius vartotojo poveikị socialiniam pritarimui ar saviraiškai. Prekès ženklas vartotojui taip pat gali asocijuotis su kokybiška arba nekokybiška produkcija bei teikti tiek teigiamas, tiek neigiamas asociacijas. Be jau minètų asociacijų, prekès ženklas gali būti siejamas ir su žmonèmis, daiktais, vietomis. Asociacijų požiūriu, prekès ženklo ịvaizdis gali būti stiprinamas savo patrauklumu, panašumus ị vartotoją ir kuriamas kaip „asmenybë“. Prekès ženklo ,asmenybe““ vartotojo atmintyje sukuria unikalių ir teigiamų savybių rinkinį, kuris savo ruožtu didina prekès ženklo vertę. Prekès ženklai ịkūnija žmogaus tapatybę, kuria žmogiškąsias savybes prekès ženklui - personalizuoja jį. Tam, kad būtų galima tirti ryšius tarp prekès ženklo ir vartotojo, Aaker (1997) pasiūlè penkių asmenybės savybių struktūrą, kurią sudaro stiprumas, kompetencija, jaudinimas, nuoširdumas ir rafinuotumas, taikyti ir prekès ženklui. Šie faktoriai sudaro 
15 bruožų grupę, kuri suformuoja prekès ženklo ,asmenybès“ matavimo skalę (žavingas, aukštesnès klasės, linksmas, naudingas, sąžiningas, praktiškas, vaizdingas, energingas, drąsus, sėkmingas, išmintingas, patikimas, laukinis, stiprus, tvirtas).

Norint, kad prekès ženklas palengvintų pirkèjų apsisprendimą pasirinkti, reikia sukurti tokị prekès ženklą, kuris pirkèjams reikštų ne tik gerą kokybę ar gamintojo garantijas, bet ir turètų savitas vertybes. Siekdamas tam tikrų vertybių žmogus patiria psichologines, praktines ir socialines pasekmes, kurios gali konfliktuoti, nesutapti su kitomis jo vertybėmis. Schwartz (2012) suformuotos vertybès atspindi individualius arba kolektyvinius interesus, arba abejus interesus drauge. Šiame tyrime, aiškinantis respondentų vertybines nuostatas, buvo remiamasi Schwartz modeliu. Schwartz (2012) išskyrẻ tris fundamentaliuosius poreikius, kuriuos turi kiekvienas žmogus ir kurie yra dešimties bazinių vertybių pagrindas - tai biologiniai, socialiniai ir visuomeniniai. Remiantis Blackwell, Miniard ir Engel (2006), išskiriami šie vertybiu tipai ir ju apibūdinimai: „Jèga“ (statusas, prestižas, turtas, dominavimas), „Pasiekimai“ (asmeninè sèkmè), „Hedonizmas“ (malonumas), „Stimuliacija“ (naujovès ir gyvenimo iššūkiai), „Saviorientacija“ (nepriklausomos mintys ir pasirinkimo laisvè, kūryba, atradimai), „Universalizmas“ (supratingumas, dèkingumas, tolerancija, „Ivairiapusiškumas“ (pagalba, nuoširdumas, atlaidumas), „Tradicijos“ (pagarba, ịsipareigojimai, gyvenimo stiliaus priimtinumas), „Atitikimas“ (mandagumas, pagarba vyresniesiems), „Saugumas“ (harmonija ir stabilumas, socialinė tvarka, švara).

Vertybių klasifikavimas leidžia atskleisti žmonių pasaulěžiūrą, nuomones, tam tikros elgsenos motyvus bei suprasti, kas yra asmeniui svarbiausia ir kas vaidina pagrindini vaidmeni, formuojant vartotojų požiūrị ir elgesị.

Kylant asociacijoms apie prekès ženklą, vartotojo pasąmonèje svarbų vaidmenį vaidina spalvos. Prekès ženklas turètų būti įmonès veidas, todèl jị atskleidžiant turi dominuoti tam tinkamos spalvos. Spalvos padeda sukurti daug efektyvesni prekès ženklą, kadangi jos atkreipia potencialaus pirkèjo dèmesį, sukelia nevalingas žmogaus reakcijas ị spalvą ar tam tikras asociacijas. Spalvos, naudojamos prekès ženkle ir kaip komunikacijos su vartotojais priemonè, gali padèti ne tik atpažinti ar įsiminti gamintoją, bet ir rodyti prekès kilmę, perteikti saugumo jausmą, sukurti prestižą ar skatinti pirkimą.

\section{Prekès ženklo, „teida“" vertybinių asociacijų analizė}

Turiningas prekès ženklo įvaizdis ir asociacijos turi derèti su įmonès elgsena, esminèmis vertybėmis ir teikti aiškią žinią vartotojams. Tyrime pateikti klausimai padèjo atskleisti, kuom remdamiesi: produkto ar paslaugos savybėmis, nauda, vertybėmis ar asmeniškumu, vartotojai vertina „Teida“ prekès ženklą. 1 paveiksle pateikiamas „Teida“ prekès ženklas.

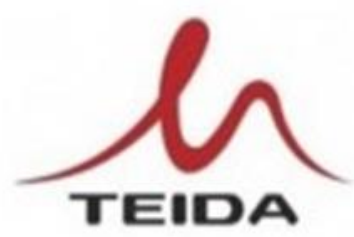

1 pav. UAB ,Teida“ prekès ženklas

Siekiant išsiaiškinti, su kokiomis asmens savybėmis labiausiai asocijuojasi „Teida“ prekès ženklas, apklausoje respondentų buvo prašoma įsivaizduoti, kad prekès ženklas „Teida“ yra žmogus, ir įvertinti, kiek jiems pateiktos žmogaus savybès yra būdingos šiam prekès ženklui (2 pav.). Iš 2 pav. matyti, kad labiausiai ịvertinta asmenybès savybė - „Jaudinimas“, kuriai priskiriami bruožai: drąsa, energingumas, vaizdingumas. Jaudinimo kategorijai priklausantys prekių ženklai dažnai siejami su muzika ar sportu, nes jie priverčia vartotoją pajusti daugiau emocijų, veržlumą ir nepriklausomybę. Antroje vietoje išskiriama asmenybès savybė „Nuoširdumas“, kuriai priskiriamas bruožas linksmumas. Šiam tipui priskiriami prekès ženklai, orientuoti i šeimą, turintys vaikystès asociacijų, ikūnijantys laimę ir džiaugsmą. Taip pat respondentai išskyre „Rafinuotumą“ ir „Kompetencijąa“. Toks 
prekès ženklo asmenybès ịvaizdis vartotojų dažniausiai suvokiamas kaip patikimas, mielas, „nekenksmingas“, pasižymi rimtumu, stabilumu, aristokratiškumu ir sukuria pasitikèjimo efektą. Mažiausiai ịvertinta savybė „Stiprumas“ - tai tipas, kuris labiausiai orientuotas ị vyrus. Tokio tipo prekès ženklo ,asmenybë“ yra vyriška, daranti ką nori, nevaldoma.

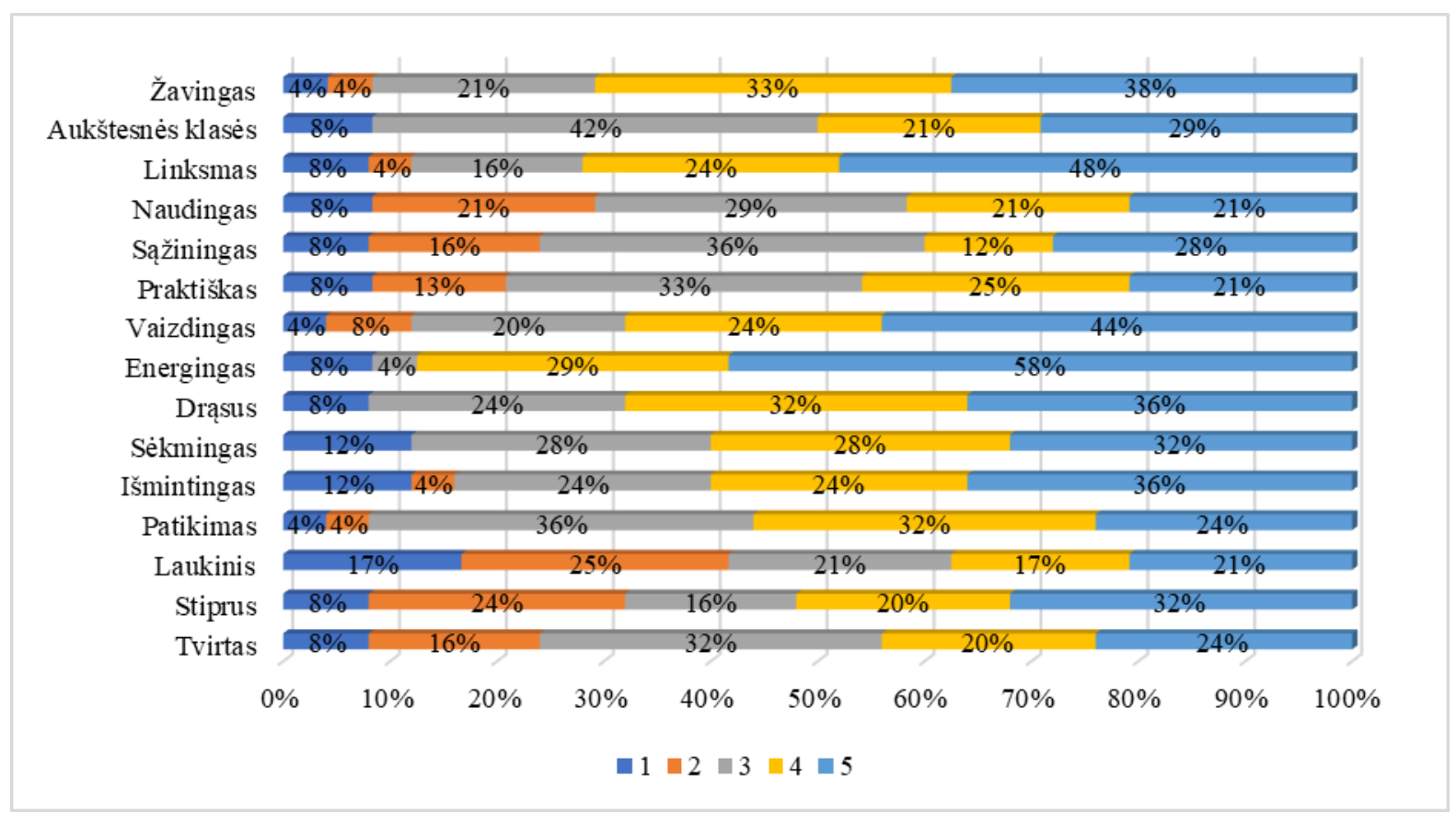

2 pav. Prekès ženklo ,asmenybès“ matavimo skalè

Šaltinis: sudarytas autorių pagal atlikto tyrimo duomenis, 2021

Prekès ženklas turi būti lengvai identifikuojamas, jame turi būti visas kompleksas asociacijų, kurias sukelia arba norima sukelti vartotojui. Palankios prekės ženklo asociacijos gali sulaukti daugelio vartotojų pripažinimo ir sąlygoti sẻkmę i̇monei, siūlančiai ši prekès ženklą. Prekès ženklas gali asocijuotis su kokybiška arba nekokybiška produkcija, klientas gali suvokti tiek teigiamas, tiek neigiamas asociacijas. 1 lenteleje pateikiamos respondentų asociacijos, kurias jiems kelia „Teida“ ženklas.

1 lentelè. Prekès ženklo „Teida“ asociacijos

\begin{tabular}{|c|c|c|c|c|}
\hline \multicolumn{2}{|c|}{$\begin{array}{c}\text { Su kuo Jums asocijuojasi prekès ženklas? (İrašykite } \\
\text { pirmą kilusią minti, emociją) }\end{array}$} & \multicolumn{3}{|c|}{$\begin{array}{c}\text { Jeigu prekès ženklas būtų žmogus, koks jis būtų? } \\
\text { (İrašykite pirmą kilusią minti) }\end{array}$} \\
\hline Teisingai atpažintos asociacijos & $\begin{array}{c}\text { Neteisingai } \\
\text { atpažintos asociacijos }\end{array}$ & $\begin{array}{l}\text { Charakterio } \\
\text { savybess ir } \\
\text { bruožais }\end{array}$ & Lytis, tautybe & $\begin{array}{l}\text { Asmenybės bruožai, } \\
\text { fiziné būklè }\end{array}$ \\
\hline $\begin{array}{l}\text { Žmogeliukas sėdi } \begin{array}{r}\multicolumn{2}{c}{\text { atsirèmęs }} \\
\text { rankomis, sulenkęs kojas per } \\
\text { kelius. }\end{array} \\
\end{array}$ & $\begin{array}{l}\text { Telekomunikacijos, } \\
\text { kosmetikos } \\
\text { pavadinimas. }\end{array}$ & $\begin{array}{l}\text { Pasitikintis, } \\
\text { viliojantis. }\end{array}$ & Vyras. & $\begin{array}{l}\text { Charizmatiška } \\
\text { asmenybė. }\end{array}$ \\
\hline Poilsis. & Azijos virtuvè. & Atsipalaidavęs. & $\begin{array}{l}\text { Graži, brandi } \\
\text { moteris. }\end{array}$ & $\begin{array}{l}\text { Fiziškai stiprus, } \\
\text { sportuojantis, } \\
\text { atletiškas, lankstus. }\end{array}$ \\
\hline $\begin{array}{l}\text { Joga, reabilitacija, judesys, } \\
\text { kamuoliai reabilitaciniai, } \\
\text { sportuojantis žmogus. }\end{array}$ & Opera „Aida“. & Nepastovus. & $\begin{array}{l}\text { Sportuojanti } \\
\text { moteris, }\end{array}$ & $\begin{array}{lr}\text { Grožis, } & \text { jaunystè, } \\
\text { sveikata } & - \text { deivė } \\
\text { Aušrinè. } & \\
\end{array}$ \\
\hline Elegancija, lengvumas. & Sèdi kažkas. & Patikimas. & Kinietis. & Padedantis. \\
\hline Sveikata. & & & & Jaunatviškas. \\
\hline $\begin{array}{l}\text { Žmogus, kuris tempia nugaros } \\
\text { raumenis, lankstumas, vingis. }\end{array}$ & & Padedantis. & & Plonas žmogus. \\
\hline $\begin{array}{l}\text { Kad atejus i parduotuvę tau paduos } \\
\text { ranką ir padès illipti i sveikatos } \\
\text { kalną, kurio pats neiveeiktumei. }\end{array}$ & & $\begin{array}{l}\text { Siekiantis } \\
\text { geriausių } \\
\text { rezultatu. }\end{array}$ & & $\begin{array}{l}\text { Profesionalus, } \\
\text { romantiškas. }\end{array}$ \\
\hline
\end{tabular}

Šaltinis: sudarytas autorių pagal atlikto tyrimo duomenis, 2021 
Remiantis 1 lentelèje pateiktais teiginiais, galima teigti, kad respondentai atpažịsta įmonès veiklos specifiką. „Teida“ prekès ženklas daugiausia kelia teisingai atpažintas asociacijas, susijusias su sportu, sveikata, fizine kūno būkle, reabilitacija, judesiu, pagalba, tai atitinka ịmonès vadovès lūkesčius - ,ịsižiūrèjus ì prekès ženklą, galima matyti sportuojančią moterị ar sèdintị ir pratimus darantị žmogų“. Pastebima keletas ir neteisingai atpažintų asociacijų, tokių kaip „Azijos virtuve““, „Kinietis“, „Opera“, „Telekomunikacija“, „Kosmetika“, šios asociacijos kilo respondentams, nepirkusiems prekių iš įmonès. Šiuo atveju, prekès ženklo ryšys su vartotoju buvo netiesioginis (per reklamą ar kitas rèmimo priemones), todèl prekès ženklo asociacijos buvo atpažintos neteisingai.

Siekiant išsiaiškinti respondentų vertybines nuostatas, jų buvo paprašyta suskirstyti ịvardintas vertybes pagal svarbą ir įvertinti balais nuo 1 iki 5, kur 1 balas - visiškai nesvarbi, 2 balai - nesvarbi, 3 balai - mažiau svarbi, 4 balai - svarbi, 5 balai - labai svarbi vertybè. Vertybinès orientacijos nustatytos, gavus atsakymus ir susumavus rezultatus (2 lentelè).

2 lentelè. Vertybių ịvertinimai pagal S. H. Schwartz vertybių grupes

\begin{tabular}{|c|c|c|c|c|}
\hline & Vertybès tipas & Reikšmė & Apibūdinimas & $\begin{array}{c}\text { Vertinimas } \\
\text { proc. }\end{array}$ \\
\hline 1. & Jèga & $\begin{array}{l}\text { Socialinė valdžia, autoritetas, } \\
\text { turtas. }\end{array}$ & $\begin{array}{l}\text { Socialinis statusas ir prestižas, žmonių ir } \\
\text { išteklių kontrole ir dominavimas. }\end{array}$ & 8 \\
\hline 2. & Pasiekimai & $\begin{array}{l}\text { Sėkmingumas, gabumas, } \\
\text { ambicingumas. }\end{array}$ & $\begin{array}{l}\text { Asmeninè } \quad \text { sėkmé } \\
\text { kompetencijas pagal socialines normas. }\end{array}$ & 46 \\
\hline 3. & Hedonizmas & $\begin{array}{l}\text { Malonumai, mégavimasis } \\
\text { gyvenimu. }\end{array}$ & Malonumai ir pasitenkinimas savimi. & 73 \\
\hline 4. & Stimuliacija & $\begin{array}{l}\text { Drąsa, ivairiapusiškas ir } \\
\text { jaudinantis gyvenimas. }\end{array}$ & $\begin{array}{l}\text { Susijaudinimas, naujovès ir gyvenimo } \\
\text { iššūkiai. }\end{array}$ & 46 \\
\hline 5. & Saviorientacija & $\begin{array}{l}\text { Kūrybingumas, smalsumas, } \\
\text { laisvè. }\end{array}$ & $\begin{array}{l}\text { Nepriklausomos mintys ir pasirinkimo } \\
\text { laisvè, kūryba, atradimai. }\end{array}$ & 77 \\
\hline 6. & Universalizmas & $\begin{array}{l}\text { Ivairiapusiškumas, socialinis } \\
\text { teisingumas, lygybè, } \\
\text { aplinkosauga. }\end{array}$ & $\begin{array}{l}\text { Supratingumas, dėkingumas, tolerancija ir } \\
\text { visų žmonių bei gamtos gerovės gynimas. }\end{array}$ & 65 \\
\hline 7. & Geranoriškumas & $\begin{array}{l}\text { Pagalba, nuoširdumas, } \\
\text { atlaidumas. }\end{array}$ & $\begin{array}{llll}\begin{array}{l}\text { Žmonių, su } \\
\text { kontaktas, } \\
\text { stiprinimas. }\end{array} & \begin{array}{c}\text { kuriais } \\
\text { gerovès }\end{array} & \begin{array}{l}\text { turimas dažnas } \\
\text { saugojimas }\end{array} \\
\text { ir }\end{array}$ & 77 \\
\hline 8. & Tradicijos & $\begin{array}{l}\text { Nuolankumas, pamaldumas, } \\
\text { gyvenimo stiliaus } \\
\text { priimtinumas. }\end{array}$ & $\begin{array}{l}\text { Pagarba, įsipareigojimai ir pritarimai mintims } \\
\text { bei idejoms, kurias sukuria tradicinè kultūra ir } \\
\text { religija. }\end{array}$ & 35 \\
\hline 9. & Atitikimas & $\begin{array}{l}\text { Mandagumas, pagarba } \\
\text { vyresniesiems. }\end{array}$ & $\begin{array}{l}\text { Žeidžiančių ir kenkiančių kitiems veiksmų, } \\
\text { polinkių ir impulsų bei socialinių lūkesčių ir } \\
\text { normų suvaržymas. }\end{array}$ & 65 \\
\hline 10. & Saugumas & Socialinė tvarka, švara. & $\begin{array}{l}\text { Visuomenės, santykių ir savęs saugojimas, } \\
\text { harmonija ir stabilumas. }\end{array}$ & 58 \\
\hline
\end{tabular}

Šaltinis: sudarytas autorių pagal atlikto tyrimo duomenis, 2021

Svarbiausiomis vertybėmis buvo įvardintos:

1. Geranoriškumas, kurị apibūdiname kaip žmonių, su kuriais turimas dažnas kontaktas, gerovès saugojimas ir stiprinimas.

2. Saviorientacija, kurią apibūdiname kaip nepriklausomas mintis ir pasirinkimo laisvè, kūryba, atradimus.

3. Hedonizmas, kurị apibūdiname kaip malonumus ir pasitenkinimą savimi, mègavimąsi gyvenimu.

Mažiausiai svarbios respondentams buvo jègos ir tradicijų vertybės tipai, kurios apibūdinamos kaip kontrolè, dominavimas, tradicinè kultūra ir religija.

Paprašius įvardinti, su kokiomis vertybèmis respondentams asocijuojasi prekès ženklas „Teida“, buvo išskirtos dvi pagrindinès vertybès: sveikata ir profesionalumas, kas taip pat atitinka ịmonès vadovès lūkesčius (3 pav.). 


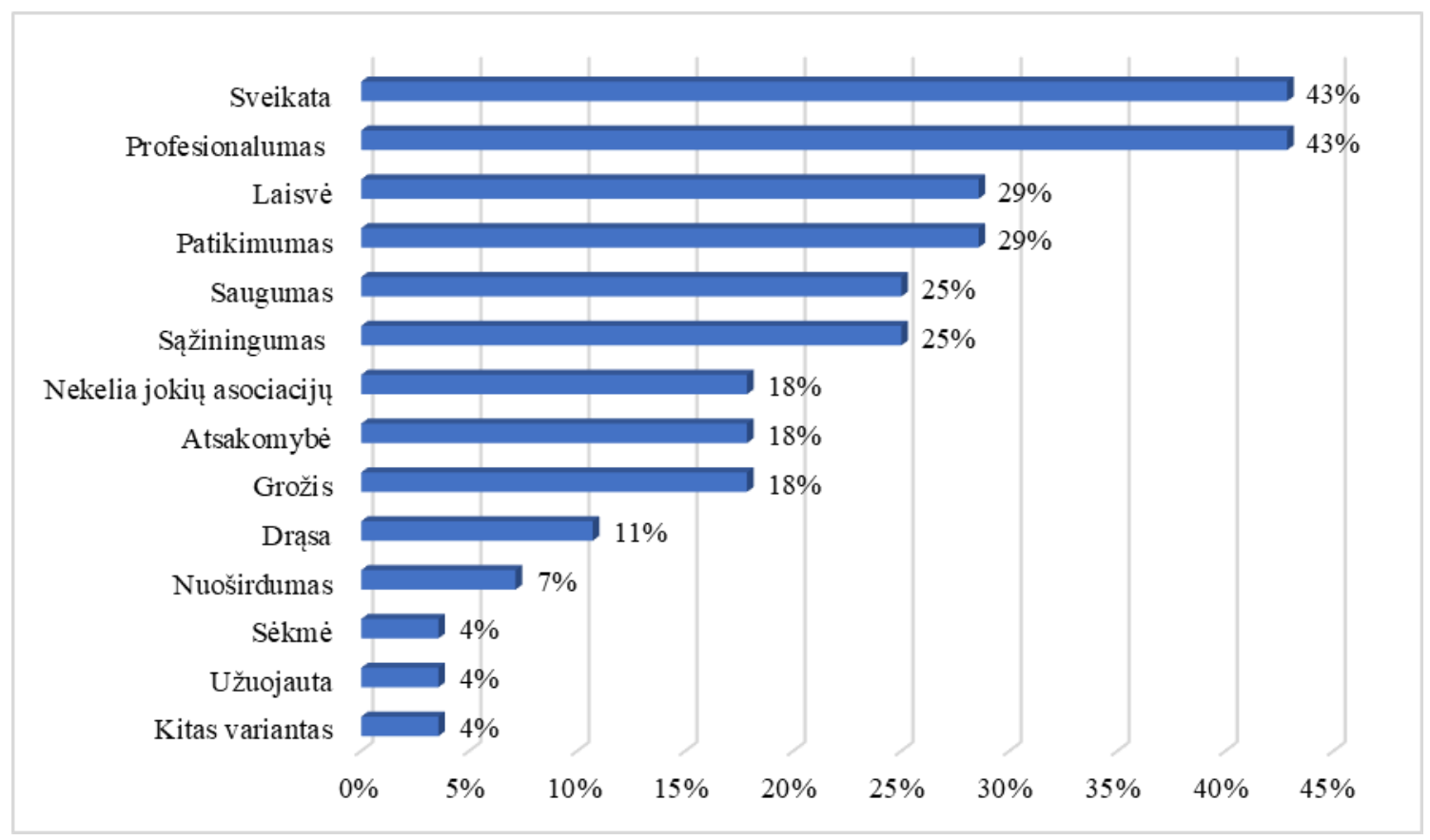

3 pav. Vertybès, su kuriomis asocijuojasi prekès ženklas „Teida”

Šaltinis: sudarytas autorių pagal atlikto tyrimo duomenis, 2021

Vertybès dažniausiai priskirtos „Teida“ prekès ženklui, atspindi tiek individualius (sveikata), tiek kolektyvinius (profesionalumas, patikimumas, saugumas, sąžiningumas, atsakomybė) interesus.

Atsižvelgiant ị spalvos svarbą, vartotojui renkantis prekès ženklą, tikslinga aptarti jų reikšmę ir įtaką, kylant teigiamoms ar neigiamoms asociacijoms. Prekès ženkle „Teida“ naudojamos dvi spalvos - raudona ir juoda. Apklausos metu buvo siekiama išsiaiškinti, kokias asociacijas respondentams kelia šios spalvos (4 pav.).

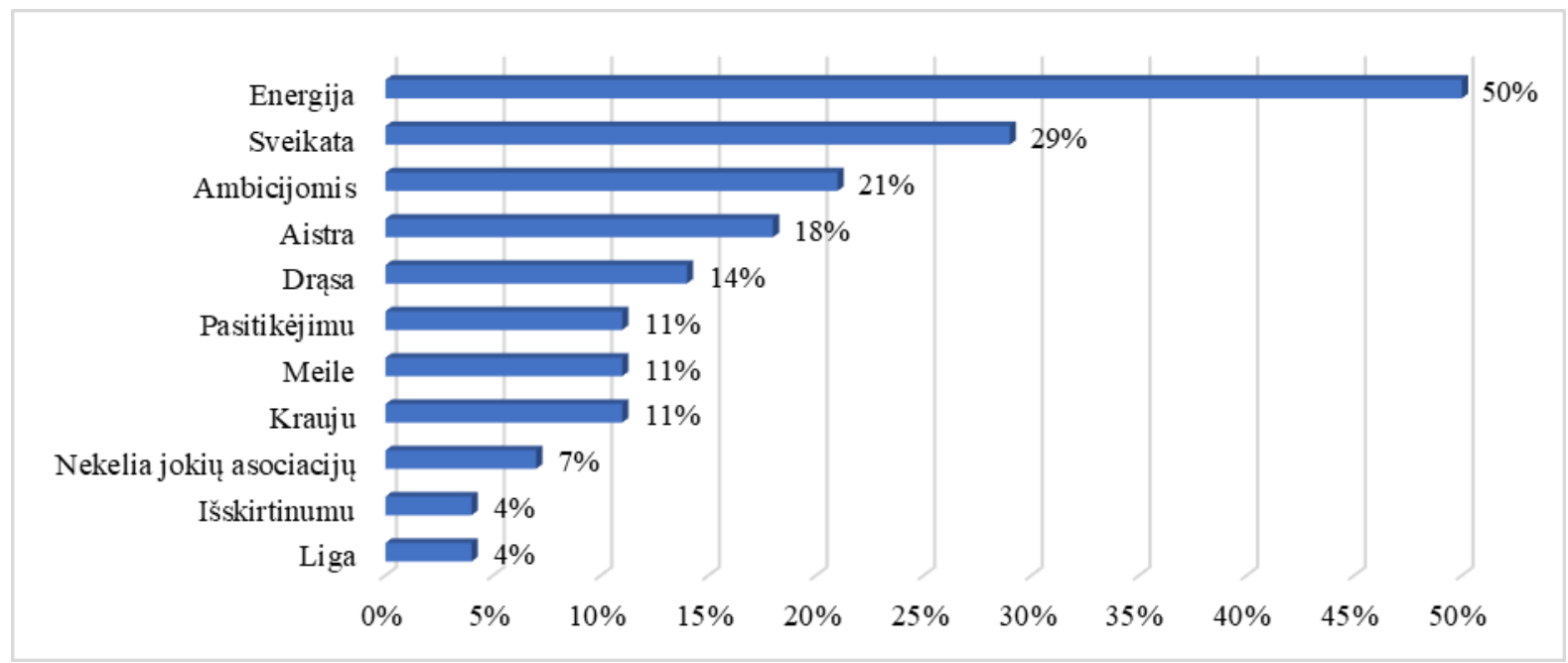

4 pav. Prekès ženklo raudonos spalvos asociacijos

Šaltinis: sudarytas autorių pagal atlikto tyrimo duomenis, 2021

Raudona spalva siejama tiek su teigiamomis (aistra, stiprumas, gyvybingumas, meilè, susižavejjimas, karštis, lyderiavimas, galias), tiek su neigiamomis (pavojus, ugnis, kraujas, karas, pyktis, agresija, pasipriešinimas, radikalizmas, naikinimas, draudimas) emocijomis. Vertindami prekès ženkle esančią raudoną spalvą, respondentai ją labiau siejo su teigiamomis emocijomis, tokiomis kaip energija, sveikata, aistra, o neigiamas emocijas keliančios asociacijos, tokios kaip liga, kraujas, kilo tik mažumai apklaustụjų.

Juoda spalva taip pat gali sukelti dvejopas emocijas: geras (galia, sudėtingumas, elegancija, paslaptis, stilius) ir blogas (blogis, mirtis, baimé, nelaimé, paslaptis nenormalumas, pyktis, liūdesys, 
gailestis). Kiekvienas žmogus yra individualus ir kiekviena spalva jam kelia skirtingas asociacijas. Respondentų asociacijos, kurias jiems kelia juoda spalva, naudojama prekès ženkle „Teida“ pavaizduotos 5 pav.

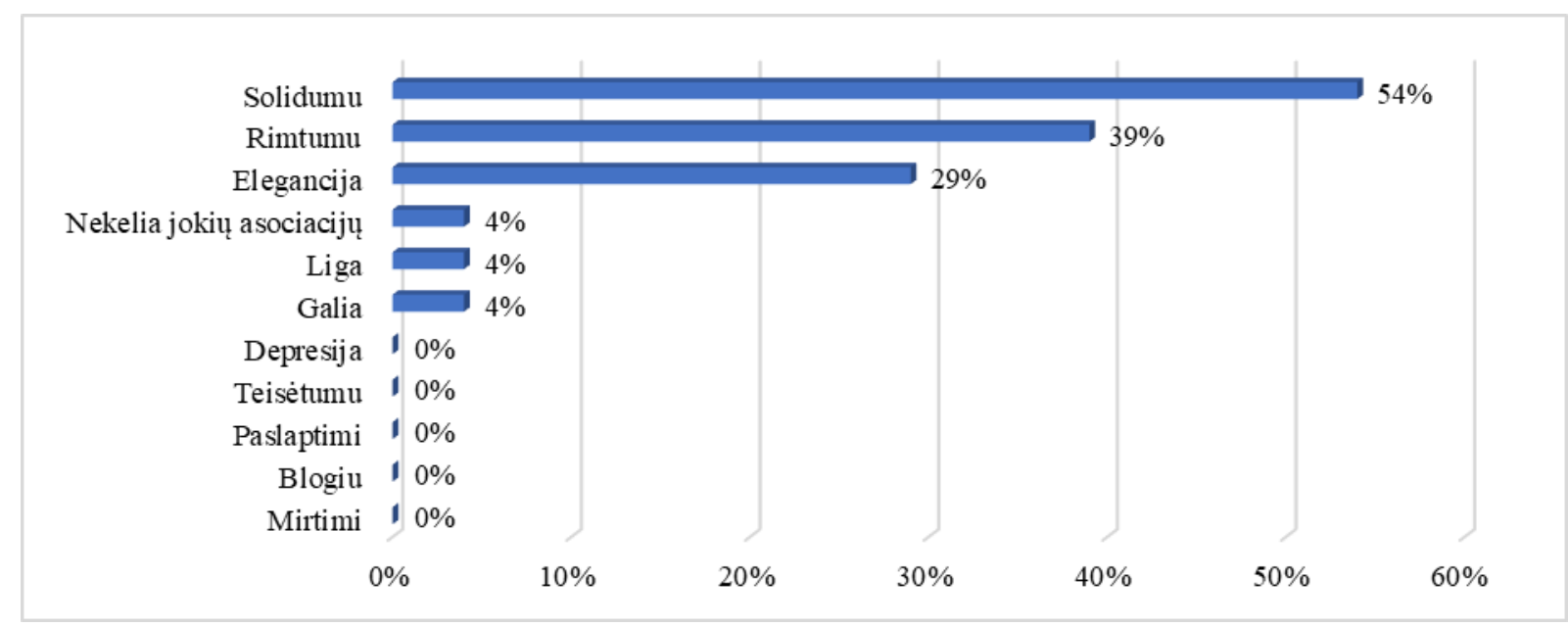

5 pav. Prekès ženklo juodos spalvos asociacijos

Šaltinis: sudarytas autoriu pagal atlikto tyrimo duomenis, 2021

Respondentų pasirinkimai parodo (5 pav.), jog juoda spalva taip pat labiau siejama su teigiamomis emocijomis ir asocijuojasi su solidumu, rimtumu ir elegancija. Iš blogas emocijas sukeliančių asociacijų buvo paminèta tik viena - liga.

Apibendrinant tyrimo rezultatus, galima daryti išvadą, kad respondentai atpažįsta įmonès veiklos specifiką. „Teida“ prekès ženklas daugiausia kelia teisingai atpažintas asociacijas, susijusias su sportu, sveikata, fizine kūno būkle, reabilitacija, judesiu pagalba, tai atitinka ịmonès vadovès lūkesčius "ịsižiūrèjus i prekès ženklą, galima matyti sportuojančią moterị ar sẻdintị ir pratimus darantị žmogų". Pastebima keletas ir neteisingai atpažintų asociacijų, tokių kaip „Azijos virtuvė“, „Kinietis“, „Opera“, „Telekomunikacija“, „Kosmetika“, šios asociacijos kilo respondentams, nepirkusiems prekių iš įmonès. Šiuo atveju, prekès ženklo ryšys su vartotoju buvo netiesioginis (per reklamą ar kitas rèmimo priemones), todėl prekès ženklo asociacijos buvo neteisingai atpažintos.

Prekès ženklui „Teida“ priskiriamos šios žmogaus savybès: „Jaudinimas“ ir jam priskiriami bruožai: drąsa, energingumas, vaizdingumas. Jaudinimo kategorijai priklausantys prekių ženklai dažnai siejami su muzika ar sportu, nes jie priverčia vartotoją pajusti daugiau emocijų, veržlumą ir nepriklausomybę. Antroje vietoje išskiriama asmenybės savybè „Nuoširdumas“, kuriai priskiriamas bruožas - linksmumas. Šiam tipui priskiriami prekès ženklai, orientuoti ị šeimą, turintys vaikystès asociacijų, ịkūnijantys laimę ir džiaugsmą. Taip pat respondentai išskyrè „Rafinuotumą“ ir „Kompetenciją“. Toks prekès ženklo asmenybès įvaizdis vartotojų dažniausiai suvokiamas kaip patikimas, mielas, „nekenksmingas“, pasižymi rimtumu, stabilumu, aristokratiškumu ir sukuria pasitikejjimo efektą. Mažiausiai ịvertinta savybe „Stiprumas“ - tai tipas, kuris labiausiai orientuotas i vyrus. Tokio tipo prekès ženklo ,,asmenybë“ yra vyriška, daranti, ką nori, nevaldoma.

Prekès ženklas „Teida“ respondentams asocijuojasi su dviem pagrindinėmis vertybėmis: sveikata ir profesionalumu, kas taip pat atitinka įmonès vadovès lūkesčius. Prekès ženkle pasirinktos spalvos raudona ir juoda labiau siejamos su teigiamomis emocijomis, tokiomis kaip energija, sveikata, aistra, solidumu, rimtumu ir elegancija, o neigiamas emocijas keliančios asociacijos, tokios kaip liga, kraujas, kilo tik mažumai apklaustujų.

\section{Išvados}

1. Prekès ženklo ịvaizdžio dalis asociacijos yra svarbiausias veiksnys, skatinantis pirkejjų apsisprendimą pirkti. Prekès ženklo asociacijų palankumas, unikalumas bei stiprumas nulemia vartotojų gebejjimą išskirti prekès ženklą tarp konkuruojančių ženklų, padeda vartotojui apdoroti 
informaciją, suformuoja teigiamą požiūrị ne tik ị patị ženklą, bet ir i prekę. Prekès ženklo kūrimo tikslas yra parengti turiningą prekès ženklo įvaizdžių ir asociacijų sistemą, o tiesiausias kelias sustiprinti vartotojų lojalumą prekès ženklui - didinti vartotojų emocinị prisirišimą.

2. Apibendrinti tyrimo rezultatai atskleide, kad prekès ženklas „Teida“ asocijuojasi su įmonès deklaruojamomis vertybėmis, t.y sveikata ir profesionalumu. Tyrimo metu nustatyta, kad: pagalvojus apie „Teida“ prekès ženklą respondentų pasąmonèje kyla teigiamos, teisingai atpažintos asociacijos, susijusios su sveikata, sportu, fizine kūno būkle, reabilitacija; "ịsižiūrèjus ì prekès ženklą, galima matyti sportuojančią moterị ar sėdintį ir pratimus darantị žmogü"; prekès ženkle pasirinktos spalvos raudona ir juoda - labiau siejamos su teigiamomis emocijomis, tokiomis kaip energija, sveikata, aistra, solidumu, rimtumu ir elegancija.

\title{
Literatūra
}

1. Aaker, J. L. (1997). Dimensions of brand personality. Journal of Marketing Research, 34 (3), 347-356. https://papers.ssrn.com/sol3/papers.cfm?abstract_id=945432

2. Aaker, D. A. \& Joachimsthaler, E. (2000). Brand Leadership. New York: Free Press (vertimas i rusų k., 2003).

3. Belén del Río, A., Vázquez, R., \& Iglesias, V. (2001). The effects of brand associations on consumer response. Journal of consumer marketing, 18 (5), 410-425. https://citeseerx.ist.psu.edu/viewdoc/download?doi=10.1.1.468.5230\&rep=rep1\&type=pdf

4. Blaccket, T., Ahmad, S., Allen, T., Anholt, S., Bahr Thompson, A., Barwise, P., Bowker, D., Brymer, C., Clifton, R., Doane, D., Faulkner, K., Feldwick, P., Hilton, S., Lindemann, J., Poulter, A., Simmons, J., Smith, S. (2011). Prekių ženklai ir ju kūrimas: istorija, verté, praktika. Vilnius: Alma littera.

5. Blackwell, R. D., Miniard, P. W. \& Engel, J. F. (2006). Consumer behavior, 10th ed. Mason: Thomson.

6. Jobber, D. (2010). Principles and pratice marketing, 6th ed. London [etc.]: McGraw-Hill.

7. Keller, K. L. (2008). Strategic Brand Management: Building, Measuring and Managing Brand Equity, 3th ed. Upper Saddle River, NJ: Pearson/Prentice Hall.

8. Navickas, V. ir Malakauskaite, A. (2007). Efficiency of Event Usage for the Increase in Competitiveness of Companies. https://inzeko.ktu.lt/index.php/EE/article/view/11478

9. Schwartz, S. H. (2012). An Overview of the Schwartz Theory of Basic Values. http://dx.doi.org/10.9707/2307-0919.1116

10. Vainauskienè, V. ir Vaitkienè, R. (2016). Prekès ženklo pažeidžiamumo scenarijų kūrimo metodologija (monografija). Kaunas: Technologija.

\section{EVALUATION OF LIMITED LIABILITY COMPANY TEIDA BRAND VALUE ASSOCIATIONS}

\author{
Jūratė Leonavičienè, Jolanta Kreišmonienė
}

\section{Summary}

The friendliness, uniqueness, and strength of brand associations determine the ability of consumers to distinguish the brand from others, help the consumers to process information, form a positive attitude not only toward the brand itself but also to the product, and help to make a purchase decision. The goal of branding is to develop a meaningful system of brand images and associations. The friendliness, uniqueness, and strength of brand associations determine the ability of consumers to distinguish the brand from others, help the consumer process information, form a positive attitude not only to the brand itself but also to the product, and help to make a purchase decision. The most direct way to strengthen consumer loyalty to a brand is to increase consumer emotional attachment. The article presents the Limited Liability Company Teida brand value association from the consumer's point of view. Teida is a specialized healthcare company that has successfully operated in the market for more than 25 years.

Research problem. Limited Liability Company Teida brand associations have not been studied from the point of view of consumers. In order to maintain leadership and strong positions in the market, it is necessary to constantly look for innovations, follow consumer moods, get to know their subconscious brand image. Therefore the research will identify Limited Liability Company Teida brand value associations and assess their compliance with the company's aspirations.

The aim of the research is to evaluate the value associations of the Limited Liability Company Teida brand. 
Methodology of investigation. 2020 April - August qualitative and quantitative studies were performed. An unstructured interview was conducted with the head of "Teida" to determine with which value associations she associates the „Teida“ brand. Quantitative research was carried out using the data collection method - an electronic questionnaire. Random probability was used to select respondents. The study involved 344 respondents.

The main results of the research. It was found that the respondents recognized the specifics of the company's activities. The "Teida" brand mainly raises correctly recognized associations related to sports, health, physical condition, rehabilitation, and movement assistance, which meets the expectations of the company's manager - "looking at the brand, you can see a woman or a person sitting and doing exercises." Several misidentified associations, such as Asian Cuisine, Chinese, Opera, Telecommunications, and Cosmetics, came from respondents who did not buy goods from the company. In this case, the brand's relationship with the consumer was indirect (through advertising or other sponsorship), resulting in the brand associations being misidentified. The Teida brand has the following human qualities: "Excitement" and attributes: courage, energy, imagery. Brands that fall into the category of excitement are often associated with music or sports because they make the consumer feel more emotional, energetic, and independent. In the second place, the personality trait "Sincerity" is singled out, to which the trait of cheerfulness is attributed. This type includes family-oriented brands that have childhood associations that embody happiness and joy. Respondents also singled out "Sophistication" and "Competence." Consumers usually perceive such an image of the brand personality as reliable, cute, "harmless," has seriousness, stability, aristocracy, and creates an effect of trust. The least rated trait, Strength, is the type that is most malecentered. The "personality" of this type of brand is masculine, doing what it wants, unmanageable. For the respondents, the Teida brand is associated with two core values: health and professionalism, which also meet the expectations of the company's manager. The colors red and black chosen in the brand are more associated with positive emotions such as energy, health, passion, solidity, seriousness, and elegance. In contrast, negative emotional associations such as illness, blood arose only for a minority of respondents.

Main conclusions. The "Teida" brand is associated with the company's declared values, i.e., health and professionalism. When thinking about the Teida brand, respondents have in their subconscious positive, correctly recognized associations related to health, sports, physical condition, rehabilitation; when they look at the brand, they see a woman doing sports or a person sitting and doing exercises. The colors were chosen in the brand, red and black, are more associated with positive emotions such as energy, health, passion, solidity, seriousness, and elegance.

Keywords: brand, value associations, consumer loyalty. 